\title{
A Quest for Originality in Latin Poetry of the Grand Duchy of Lithuania Observed in Manuscripts of the Seventeenth-Eighteenth Centuries
}

\author{
ŽIVILĖ NEDZINSKAITE்
}

\begin{abstract}
The seventeenth and eighteenth centuries were the time when literature in Latin written by professors and students of Jesuit colleges flourished in the Grand Duchy of Lithuania. This trend was the outcome of the Jesuit educational model. The main disciplines in colleges were poetics and rhetoric. The classes of these two disciplines not only aimed at teaching theoretical rules, acquainting the students with the prevailing literary canon, and pointing out the differences between genres, but also encouraged students' individual creative work, as it was independent writing that was a proof of students' ability to apply theory in practice. Student writing was strongly influenced by the theory of imitation, which was very popular at the time. Resorting to manuscript material from the colleges of the Grand Duchy of Lithuania, the article focuses on varying degrees of influence of the imitation theory on students' individual creative work: it shows the relation between imitation and the literary tradition, the rules of rhetoric, and imitation of canonical authors; it also places emphasis on the quest for individual expression. The author observes that some texts composed by students are on a par with the best poetic works of the well-known poets of that time.
\end{abstract}

Keywords: Neo-Latin Literature; poetics; rhetoric; Jesuits; manuscript; Grand Duchy of Lithuania

\section{Introduction}

The Jesuits, who established themselves in the Grand Duchy of Lithuania in the late sixteenth century, livened up the existing yet scarce literature in Latin and became its main representatives. Educational institutions founded by them (Vilnius Academy in 1579 and other colleges) contributed significantly to the process of creation of such literature. At the lessons of poetics and rhetoric, the students of these colleges were taught the fundamentals of how to write works of certain genres, which they applied in their individual work later. They did not stop at that, though: resorting to established rules, they searched for opportunities of new ways of expression. Creative work of many a better-known 
Baroque author of the Grand Duchy of Lithuania has already been examined from this point of view, so this article will be focused on revealing the process of individual creation of that time, that is, on showing how the Jesuit students used to gradually progress from versification practice at poetics lessons to composing complex and original works.

The article consists of several parts. It opens with an overview of the main peculiarities of the Jesuit educational system that shaped the students' worldview and their taste in literature. This is followed by a discussion of the imitatio theory in seventeenth-century rhetoric and its influence on the creative work of students of that period. Finally, using examples of poetic creation, the students' works are analysed, their relation with the literary tradition, rules of rhetoric, and imitation of canonic authors is shown, and the search for individual expression is highlighted. The article is based on seventeenth-century manuscript notes of poetics and rhetoric lessons, and samples of students' creative work from the colleges of the Grand Duchy of Lithuania.

\section{Peculiarities of the Jesuit Education System}

For the first time, members of the Society of Jesus systematically adapted the traditional teaching syllabus and methods to a wide network of educational institutions. All Jesuit-run schools followed a common standard educational project. It rested on several main aspects: originality of the syllabus, gradual progress from a lower to a higher level, and well-trained teachers. In these schools, order and method played the central role. The German scholar Heinrich Böhmer referred to the Society of Jesus as the order of teachers and scholars, as the largest educational organization that had ever existed in the world, because the majority of its members were students and professors (Böhmer 1904: 122). It is important to note that the Jesuits were in charge of colleges and universities. One of their aims was to teach students to speak Latin and to write in Latin at the level of their native language or even better. Such a purpose resulted in other aspects of education: the Jesuits were involved not only in the education of young people but also in their nurturing. Another feature of Jesuit education was stirring of the students' ambition and competitiveness, which were encouraged through annual examinations, school ceremonies, disputes, poetry recitals, drama performances, and other similar public events. Other things that made Jesuits schools attractive were free tuition, the academic titles conferred, care of the students' material and spiritual life (Böhmer 1904: 122-129). 
The Jesuits went for the humanistic teaching method (Natoński 1970: 311312), as, in their opinion, it was the most effective in nurturing the strength of the students' character and their piety. This model rested on the studies of Classical languages - Latin, Greek, and to some extent Hebrew. Empirical and formal disciplines (history, geography, mathematics) were paid considerably less attention (Šidlauskas 1989: 18). Having absorbed the key principles of humanistic education, the Jesuits created a typical model of a college, which consisted of classes of grammar (most often divided into infima, grammar, and syntax), poetics, and rhetoric. In a college, studies of all these disciplines usually took from five to seven years. After that, students could expand their education at the university, first at the faculty of philosophy (three years) and then at the theological faculty (four years) (Rabikauskas 2002: 8-10).

One more peculiarity of the Jesuit system of teaching deserves mention, and it is the teaching practice that was obligatory to almost all students. They were supposed not only to be highly qualified but also to apply what they learned, and to convey it in a clear and convincing manner. Therefore, teaching grammar, poetics, and later rhetoric was a usual path for many master students (Piechnik 1984: 89). Prior to embarking on studies of philosophy, the Jesuits had to teach classes of infima and grammar for one or two years. Graduates of philosophy were sent to teach poetics, and only theology graduates were allowed to teach rhetoric or philosophy. It should be noted that Jesuits' methods were insightful and democratic; attempts were made to engage various talents of their students, as effectively as possible, in the activities of the Society of Jesus. In case it turned out that a student was not suitable for pedagogical work, he was appointed a preacher, became involved in missionary work, or took up administrative duties in the system of the Jesuit Order (Ulčinaite 1979: 10).

The Jesuit educational system was based on Ratio studiorum (1599) - regulations that clearly outlined the rules of each level of teaching (grammar poetics - rhetoric - philosophy - theology). Literary works were more extensively introduced at the classes of poetics and rhetoric. Rhetoric was given considerable attention in Ratio studiorum: the duties of the professor of this discipline and the teaching methods to be applied were set out in the chapter Regulae professoris rhetoricae (Ratio 1603: 133-142). Teaching of rhetoric consisted of two parts. First of all, it was reading and analysis of the works of antiquity, and explaining what was characteristic of different genres. Later rhetoric studies involved independent writing of works in different genres in imitation of authors read or selected. Ratio studiorum gives a standard pattern for the analysis of any work. Following it, the teacher first of all explains the meaning of a work and offers possible variants of interpretation. This is followed by a discussion about the composition and the ways of artistic 
expression, examples are given of how other authors wrote while using similar means of expression. In addition, ideas of the work analysed were supported by the thoughts and maxims of other authors. Finally, the students are recommended to explain the realities of the work that bear associations with history, mythology, geography, and so on, and to pay attention to the originality of individual words and expressions. The theoretical part was followed by practical tasks: to write a work in one of the genres imitating the style of an author read (Ratio 1603: 141-142). Students' independent literary creative work was a higher stage that was usually practised exclusively in the rhetoric class. Such practice not only helped to internalise theoretical information, but quite often revealed students' talent for poetry or prose writing. It was for this particular reason why Jesuit schools relied so heavily on the development of writing skills and on the imitation of a chosen or suggested author.

\section{Imitation as the Spiritus movens of the Baroque Epoch}

In the works of the outstanding sixteenth-seventeenth-century literary theorists considered central in studying poetics and rhetoric at European universities, huge emphasis was put on the significance of imitation. It was explained as a permanent process of improvement that evolved in stages, and genuine mastery in poetics was not blind imitation of the style or lexicon of one author or another, but an original interpretation of the idea or sensations revealed in a certain work, or an independent and rather distant from the original version of that same motif.

In the work Poetices libri septem ${ }^{1}$, the theorist of Renaissance literature Julius Caesar Scaliger (1484-1558) maintained that poetry was a science, and a poet's aim was to compose works in accordance with the rules of this science; the works were to be imitations and to educate the reader (Scaliger 1586: 6-7). He also noted that one could become a poet when attaining improvement in two directions: by training the skills of imitation (imitatio) and taste, and those of a particular literary perception (iudicium). In the ideal case, a poet should combine these two qualities in his work (Scaliger: 1586: 537).

Scaliger's literary theory was taken further by one of the most prominent Jesuit philologists Jacobus Pontanus (1542-1626). He discusses imitation in the first three chapters of his work Poeticarum institutionum libri tres (1594) and sees it as an integral part of poetics. The scholar claims that imitation is of two

1 Scaliger's work was first published posthumously, in Lyon in 1561. The author of the article referred to later edition of 1586 . 
kinds (duplicem esse imitationem). One kind is simpler, when to imitate means to copy to some extent (imitari effingere quippiam significare). The other kind is much more complex and demands greater talent and poetical skills from the poet. According to Pontanus, such imitation should be undertaken only after a considerable preparation: in his opinion, a poet should set one author as an example to follow and even to surpass, and if he notices a certain shortcoming in that author's work, he should search for the missing means of poetic expression in the works of others (Unus praecipue deligendus, cui nos similes esse studeamus, cui si quid deest, nullo negotio ab aliis petere licebit) (Pontanus 1609: 16-17).

Imitation used to be taught at the poetics and rhetoric classes at the Jesuit colleges of the Grand Duchy of Lithuania ${ }^{2}$. Like recognized literary theorists, the professors who taught imitation at those schools considered it one of the critical components of the teaching process. Many a teacher would begin the classes of poetics with a discussion of poetry as such (de poesi in genere). According to them, an ideal poet is shaped by four main things: natura, ars, exercitatio et imitatio (innate talent, mastering of the rules, practice, and imitation of chosen authors). They placed special emphasis on practice and imitation. Numerous notes of poetics classes indicate that in order to become a good poet or orator, one had to practise reading (lectio), exercise (exercitatio), annotation (annotatio), and imitation (imitatio) on a daily basis. The aim of lectio was to choose a favourite author and to read his works. Exercitatio was directed at memorizing fragments of these works or at attempts to compose something similar, or use examples provided by teachers. Annotatio taught and helped to select quotations and phrases from a work read that could be used in one's own work, and imitatio encouraged writing of works resembling those by the author read (Nedzinskaite 2011: 139).

Imitation was one of the critical and most complex stages in teaching poetics and rhetoric. Professors of Jesuit colleges used to explain imitation at the very beginning of the taught courses, immediately after the sections on the essence of poetry, its purpose, and the aims set to a poet. The first chapter in poetics is quite often called De imitatione ('On Imitation'). It points out that imitation of various authors is very important in mastering the art of rhetoric and a sound foundation for independent literary creation.

The concept of imitation was approached rather differently in college courses of poetics and rhetoric. Teachers would introduce the following definitions of imitation: 'imitation is like formulation of an idea on the basis

The author used notes of poetics and rhetoric classes kept at the Manuscript Department of the Vilnius University Library. In this article they will be indicated by the abbreviation VUB RS. 
of read authors' (imitatio est conformatio authoribus tanquam alicui ideae, VUB RS F 3-1392: 7), 'imitation is the expression of the thought introduced and perfected in his work by the one who we are imitating' (imitatio est expressio rationis, quam is, quem imitamur, in opere suo perficiendo tenuit, VUB RS F 3-2188 1694: 60), 'imitation is nothing else but formation of our language after the rules or language and style of the author we are imitating' (imitatio nihil aliud est quam confirmatio sermonis nostri ad normam sermonis, seu styli eius authoris quem imitamur, VUB RS F 3-1364 1703: 39). The given definitions show that imitation is understood both as absorbing the lexicon or the style of a chosen author, and a transformation of the main idea of a work.

Still, despite the versatile nature of the definition of imitation, the majority of teachers at Jesuit colleges associated this process with not as much as verbatim incorporation of phrases of a chosen author into their own work as with an original - frequently new - interpretation of an idea expressed in a work of a favourite author. A multitude of synonyms of the term 'to imitate' (imitari) are a proof of such an approach: to consider (considerare), to prove (observare), to perceive (intelligere), to evaluate (expendere), to rival (aemulari) (Nedzinskaitè 2011: 141).

Sometimes, when explaining the essence of imitation, teachers used to resort to a vivid analogy with another branch of art, painting. They maintained that imitation resembles a finished painting. The painter as if echoes the chosen moment from the reality of life or surrounding nature, but conveys it in one's own brush strokes and in one's own colours. Therefore, the resulting image or scene, although it resembles the original, is not a mirror image of it. Something similar happens with a literary imitation (VUB RS F 3-938 1734: 60, VUB RS F 3-1392: 7).

In theoretical works of the seventeenth century, imitation is compared to three stages of the human life. When imitating an author or a work, a poet seems to pass through three stages of life and creation: childhood, youth, and maturity. Correspondingly, imitation can be literal or childish (incipiens seu puerilis); it has its attitude to things being imitated, that is, it is youthful (crescens), and then one chooses to follow only the best, in other words, imitation is mature (adulta) (Ulčinaite 1995: 200).

It is important to note that almost all college courses of poetics and rhetoric distinguished between two types of imitation: imitatio verborum (imitation of words) and imitatio rerum (imitation of content). An anonymous eighteenthcentury professor of poetics thus defines these forms of imitation: in the former case, the eloquence and words are imitated (alia imitatio eloquentionis seu verborum), and in the latter case, it is an imitation of feelings experienced while reading a particular work (alia imitatio sensuum) (VUB RS F 3-1395: 56). 
NEDZINSKAITE்

\section{A Quest for Originality in the Creative Work of the Students of Jesuit Colleges}

Practice at the poetics and rhetoric classes of the colleges in the Grand Duchy of Lithuania was indeed patient and abundant. This is demonstrated by numerous seventeenth-eighteenth-century manuscripts that record the creative work of college students. In this article we will show how the theoretical rules of imitation learnt in classes were applied by the students in creating works of different genres.

One of the interesting manuscripts comes from $1651 .^{3}$ It consists of students' poetry: works composed in different metres in Latin and Greek written in Vilnius and Nesvizh. One poem from this collection of student poetry is a perfect example of how a work of a different meaning is composed on the basis of imitatio verborum rules. It is a work written in imitation of the $110^{\text {th }}$ epigram, 'The Word of Christ on the Cross: I Am Thirsty' (Christi in cruce vox: Sitio), by the well-known poet Mathias Casimirus Sarbievius (1595-1640). It was written by Jan Ważyński (1633-1661), then a student of rhetoric who later studied theology at Collegium Romanum in Rome, worked in the Czech province and taught philosophy in Poznan.

Sarbievius's epigram is based on the story about the death of Jesus from The Gospel According to John:

Postea sciens Iesus, quia iam omnia consummata sunt, ut consummaretur scriptura, dixit: Sitio. Vas ergo positum erat aceto penum. Illi autem spongiam plenam aceto, hysopo circumponentes, obtulerunt ori eius. Cum ergo accepisset Iesus acetum, dixit: Consummatum est, et inclinato capite tradidit spiritum (Jn 19, 28-30).

(Later, knowing that everything had now been finished, and so that Scripture would be fulfilled, Jesus said, "I am thirsty." A jar of wine vinegar was there. They soaked a sponge in it, put the sponge on a stalk of the hyssop plant, and lifted it to Jesus' lips. When he had received the drink, Jesus said, "It is finished." With that, he bowed his head and gave up his spirit.)

In the epigram, this episode of the Bible is expanded and its poetical interpretation is given:

Ah! Sitio, clamas, princeps pulcherrime rerum:

Non habeo pro te dulcia vina: siti.

Tu tamen, Ah, sitio, clamas; dabo pocula, Sponse:

Heu mihi! Sed misto pocula felle dabo.

3 VUB RS F 3-68. 
A Quest for Originality in Latin Poetry of the Grand Duchy of Lithuania

Haec, mi Sponse, bibe: quaeris cui forte propines?

Ad me pro mundi, Christe, salute bibe.

(Oh! I am thirsty, you cry, the most beautiful ruler of things; / I do not have any sweet wine for you: do suffer from thirst. / Yet you cry: oh, I am thirsty; I will give you a goblet, Betrothed: / oh my! But I will give you a goblet of drink diluted with bile. / My Betrothed, drink this: are you looking for somebody to drink with? / Drink to me for saving the world, Christ.)

Sarbievius conveys Christ's suffering on the cross through a dialogue. It can be understood as a dialogue between the Betrothed - Christ and the implied Bride Elect - the subject of the epigram, possibly a Jesuit. Christ is asking for a drink, but his interlocutor does not have any sweet wine that would quench the sufferer's thirst. Wine is like the elixir of life, a drink of immortality symbolizing salvation, joy, and fulfilment (Becker 1996: 306). Upon Christ's repeated cry 'I am thirsty', the second figure of the epigram resolves to offer him a goblet of drink diluted with bile. The closing lines of the epigram contain the thought that sums up the dialogue: quenching Christ's thirst, that is, saving souls and the world, is possible only by drinking a goblet of suffering, and that is what the goblet of bile-diluted wine offered to Christ before his death symbolises. This is the goblet that the subject of the epigram promises to use after Christ's death, in this way as though sharing Christ's suffering and to contribute to salvation both of his own soul and of the whole world.

Ważyński titled his epigram 'On the Blessed Martyrs of the Society of Jesus' (De B. Martyribus Soc. Iesu) and interpreted Sarbievius's text in his own way:

Ah sitio clamas, Princeps pulcherrime rerum, Non habeo pro te, dulcia vina: siti.

Tu tamen ah sitio clamas, sed pocula desunt, Heu mihi quid faciam, quae dabo vina tibi.

Sed cur tam tristes gemitus de pectore fundo, Cur longo quaero tempore vina Deo.

In Cruce tres botri pendent, hos carpito Christe

Transfixi telis, absque labore bibes.

(Oh! I am thirsty, you cry, the most beautiful ruler of things; / I do not have sweet wine for you: do suffer from thirst. / Yet you are crying: Oh, I am thirsty, but there is no goblet, / oh my, what shall I do, what wine will I offer you. / But why do I pour such sad laments from my chest, / why is it taking so long to look for wine for God. / Three grapes are hanging on the Cross, pierced by lances, / take them, Christ, you'll drink them without trouble.) 
Ważyński's epigram is of eight lines, Sarbievius's has six. The starting point of the work is word-for-word rewriting of the first two lines of Sabievius's epigram. Lines 3 and 4 do not digress much from Sarbievius's poem, but the accents of meaning change by changing several words. In line 3, Ważyński changes Sarbievius's words dabo pocula, Sponse (I will give you a goblet, Betrothed) to his own, sed pocula desunt (but there is no goblet). In line 4, Sarbievius's words Sed misto pocula felle dabo (but I will give you a goblet of drink diluted with bile) that follow the expressive exclamation Heu mihi (oh my) were changed by Ważyński to quid faciam, quae dabo vina tibi (what shall I do, what wine will I offer you). The rhetoric student added lines 5 and 6, and at the end (lines 7-8) he returns to the motif of the goblet of suffering in Sarbievius's epigram, modifies it slightly by adapting it to his chosen theme and ends the epigram with the same word as Sarbievius (bibe and bibes).

Ważyński's epigram is very likely dedicated to three Jesuit missionaries who continued Francis Xavier's work after the latter's apostolic mission in Japan. They were Paul Miki SJ, 33, who was about to become a priest and preached extensively in his country, Johannes Goto, 18, and Jakob Kizayemon SJ, 64. Under the emperor's order, these three Jesuits were arrested in Kyoto and forced to march to Nagasaki during the winter. This forced march, however, turned not into humiliation but into honour of Christian faith, because in such circumstances they kept converting people to Christianity. In 1597 in Nagasaki, the three Jesuits along with 23 Fransciscans monks were crucified and pierced with lances. They were beatified by Pope Urban VIII and canonized by Pope Pius IX in 1862.

The young Jesuit as if offers the martyrdom of his brothers to Christ and simultaneously voices his resolve to accept this martyrdom himself. At the end of the epigram the three martyrs are symbolically depicted as three grapes. The cross is like a tree and Christ is a vine around it; the viable stem supports the believers, the small growths of the vine. It means that the Jesuit martyrs, too, are the ends of the cross on which Jesus was crucified, and in this way they have joined his suffering and the sacrifice made for the salvation of the world. Like Christ, the martyrs are pierced with lances, while the blood seeping from their wounds as if quenches Christ's thirst and revives him.

Ważyński's imitation of Sarbievius's $110^{\text {th }}$ epigram is quite talented. Shifts in meaning in lines 3-4 correlate with the rhetoric questions in the newly added lines 5-6. The end of the epigram preserves the Christian message and the Jesuit fervour in salvation work conveyed by Sarbievius's epigram. The concept of Ważyński's epigram - an ingenious fusion of the opposites - is contained in its closing lines, where the martyrs' blood is given to Christ to drink: through suffering they join the salvation of the world. 
A Quest for Originality in Latin Poetry of the Grand Duchy of Lithuania

We have already pointed out that Ważyński's epigram can be considered an example of imitatio verborum. Meanwhile, an example of artificial poetry from a 1695 collection of works by students of rhetoric of Kražiai College will illustrate imitatio sensuum. ${ }^{4}$ This is a rather rare work in the poetry of the Grand Duchy of Lithuania, in the shape of a flag, composed by Georgius Barszcz (1677-1743) who later taught at numerous colleges and was the provincial of the Jesuit province of Lithuania.

It is quite likely that Barszcz was inspired by the acrostic in a flag-shaped work by the Piarist monk Ignacy Krzyżkiewicz (1640-1695) published in the work on rhetoric Attica Musa $(1674)^{5}$ - acrostic (p. 61), dedicated to John Sobieski (1629-1696), King of Poland and Grand Duke of Lithuania. ${ }^{6}$ Presumably, the work was composed after Sobieski's victory at the Battle of Khotyn in 1673. The victory was indeed impressive: joined Polish and Lithuanian troops 30,000 strong defeated 35,000 Turkish warriors under Hussain Pasha well established in Khotyn castle. The losses of the battle were also revealing - 5,000 casualties on the Lithuanian-Polish side against 30,000 killed Turks (Orłowski 2007: passim). The Battle of Khotyn was won on 11 November 1673, and on 19 May 1674 Sobieski was elected King of Poland. Since Attica Musa appeared in that same year, it is quite possible that its author adapted the flag-shaped text and dedicated it to the new king (fig. 1).

4 BCz 1866 IV: Fructus horni [---]. This collection of almost 700 pages consists of various occasional works: prose, poetry, and artificial literature.

5 Attica Musa Thitoream et Hyampeum, Parnassi colles, ultro et citro pervolans, seu epitome artis poeticae authore $p[a t r e]$ Ignatio a $S[$ ancto] Francisco religionis $P . M$. D. Scholarum Piarum Anno Symbolico / VICtor, DIVes opVM sIt / Rege Ioanne PoLonVs, Cracoviae: Apud Albertum Gorecki, S. R. M. Typ., 1674.

6 There is no doubt that the library of Kražiai College had this work, see Elenchus librorum veteris collegii Crosensis anno 1803 compilatus. 2017. 
In nova non vano sexcenti stemmata plausus

Omine Fama trahit, Lechici dum munera sceptri

Aurea qui capiat, Patriis inventus in arvis

Nobilis a Geticae prostrato robore Lunae, Nobilis a pleno magnis Dux orbe triumphis.

Et iam Sarmatiae sociis volat aemula campis

Sublimis Fortuna novos trabeata decores,

Sub superas volat usque plagas. Iam Lechicus ales

Occiduos despectat agros ac augure voce

Bistoniis tandem promittit funera regnis.

In patulis Pax errat agris, et Vandalus undas

Eggerit ipse suas, auro ditissima surgunt

Saecula, quae Thracicus motis nec tangat arenis

Contus, nec dubiis confringant fata procellis.

I, Rex, i, quo Te magnus Tuus excitat ardor;

Undique fata favent, Orbis Te Principe crescet

Sarmaticus, primae repetetque insignia famae.

$\mathbf{R}$

E

$\mathbf{X}$

$\mathbf{P}$

$\mathbf{O}$

$\mathbf{L}$

O

$\mathbf{N}$

I

AE

3.

(A rumour weaves prophetically abundant applause into new wreaths, at the time when a new leader emerges in the native land, a leader famous for defeating the strength of the Getic moon [i.e., the Turks], famous for meriting numerous triumphs around the world, it is him who will undertake the duties of Lech golden sceptres [i.e., will become a king]. And Fortuna is flying high above, adorned in new ornaments, she is competing against the neighbouring Sarmatian fields [i.e., against the glory of the military leaders of neighbouring lands], she flies up to the high skies. And the Polish bird [i.e., the eagle in the Polish coat of arms] already takes in the western lands, and finally promises the collapse of the Bistonian kingdoms in a prophet's voice. Peace settles in wide fields, and the Vandal [i.e., the Vistula] surges in waves, and golden ages rich in gold are coming, which will not be disturbed by the Thracian lance that sparked the wars, nor will the fate wound with treacherous storms. Go, King, go where your great courage is calling; everywhere your fate is guarding you, under your rule the Sarmatian world will prosper and regain the symbols of its original fame.) 
A Quest for Originality in Latin Poetry of the Grand Duchy of Lithuania

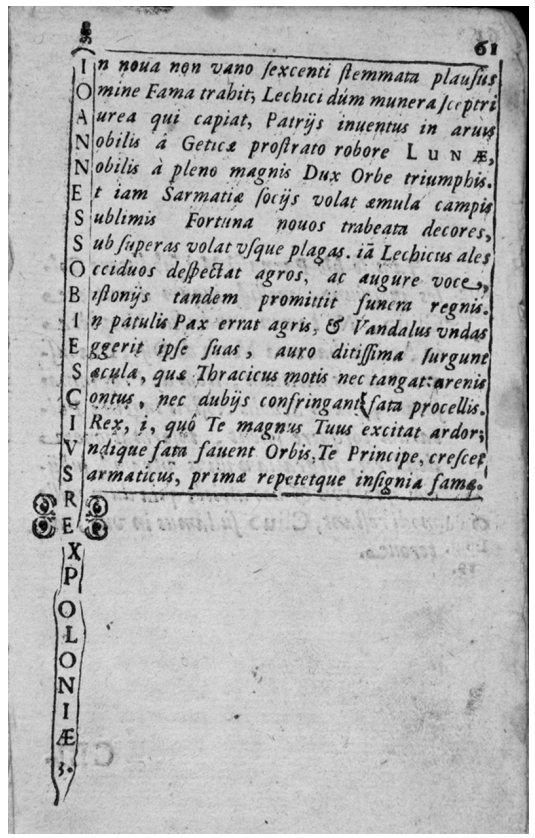

Fig. 1.

This work glorifies the king's courage on the battlefield. In this acrostic, which is written in hexameter, we will find many clichés used by the poets of antiquity (Fama trahit - rumour carries, that is, rumour is spreading; auro ditissima saecula - the golden age is coming) ${ }^{7}$ and symbols established in the eighteenth century (Getica Luna - Getic moon, that is, the Turks; Bistonia regna - Bostinian kingdoms, that is, Turkish lands). The poem ends with an optimistic wish to the king, while first letters of each line form the phrase 'Ioannes Sobiescius, rex Poloniae 3' (John Sobieski, King of Poland III). The form of the poem is symbolic and non-traditional. The flag is associated with power, courage, military glory, honour, and loyalty (Becker 1996: 300), and embraces all symbols of labarum. ${ }^{8}$ One might assume that the text within the shape of the flag is also a symbol of Sobieski's victory (a flag held by Christ or a lamb symbolises resurrection and a victory over the forces of darkness),

7 Cf.: Horatius Flaccus, Odes, I, 2; Publius Papinius Statius, Thebais, XII, 107; Publius Ovidius Naso, Metamorphoses, I, 1.

8 The night before the decisive Battle of the Milvian Bridge against Maxentius (in 312), Constantine the Great dreamt of, saw, or heard (according to a different version) the

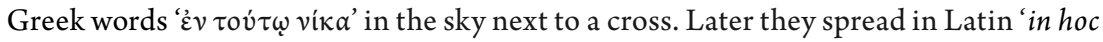
signo vinces' (in this sign you shall conquer), and eventually were abbreviated to IHS. 
NEDZINSKAITE

with which he, like Constantine the Great, not only defeated the enemy of Christianity on the battlefield, but also consolidated the positions of the true faith.

Georgius Barszcz borrows the shape of the poem - the flag - from Krzyzkiewicz, and fills it not only with complex acristic elements, ${ }^{9}$ but also with deep religious content (fig. 2).

Iuratus tua signa sequor, dux optime bellI,

Victricesque aquilas, aquila autem, dux meus es tV.

Romuleae periere aquilae; tibi militat aethe $\mathbf{R}$,

Auratae aligerumque acies et pontus et aurA,

Terra, fretum. Iesus super omnia sidera regna $\mathbf{T}$

Victaque terrifico consternat Tartara nutV.

Solis esse licet sub te ductore beatiS.

Tali pacta fides ritu desponsaque fausta esT.

Vna salus tua signa sequi, bone dux pie IesV.

Absit vero scelus turpe, absit dedecus ist $\mathbf{A}$

Signa parata creare triumphos demere belliS

Infami effugio: proh, degener iste periclI

Gratis corda timor, mera naenia vel licet et hinC

Nulla theatralis formido, non Stygis agmeN

Adstantem signis, non lux percellet avarA,

Sacra Tagi sitis aut dona insidiosa DioneS.

Eminus is splendor labari aemula tensa pavorE

Quotquot erunt feriet: semper victoria signum hoC

Vestigat viridique ornat sacra culmina laurV.

$\mathbf{O}$ nunquam averso bellantia signa GradivO

Regali propiora throno! Nunquam inde revellaR.

(Having sworn [i.e., having taken monastic vows[, I am following your flags [choosing military service in your troops[, the best military leader [i.e., Christ], / and the victorious eagles [here, the eagle is probably understood both as the symbol of Christ's legions - the believers, and that of Gods omnipotence and the power of faith], and You [i.e., Christ] are my eagle and general. / Romulus's eagles perished [i.e., the old Roman Empire, a pagan kingdom, collapsed], while Heavens are on your side / and ranks of angels shimmering in gold, and depths, and winds, / the earth [i.e., humanity] and the sea. Jesus rules above all constellations [i.e., is the ruler of the whole world] / and threatens the defeated

9 The words on the sides of the flag and in Christ's monogram: Iuratus tua signa - tessera pugnae sequor. Iesus paupertatis, castitatis, obediantiae exemplar est (Sworn I follow your flags - the signs of faith. Jesus is an example of poverty, chastity, and piety). 
A Quest for Originality in Latin Poetry of the Grand Duchy of Lithuania

Tartar [i.e., hell, the unbelievers] with a terrible order [very likely the resurrection of Christ from the dead, the victory over death is meant]. / Only by obeying you [following you] one is fated to be happy [i.e., be salvaged, taken to heaven]. / Only thus made and sworn vow [i.e., faith] is a success [reference is made to monastic vows]. / The only salvation is following Your flags, $\mathrm{O}$ good leader, merciful Jesus. / Deliver us from the shameful crime and infamy of withdrawing flags, aimed at picking victories, from a battle by fleeing disgracefully [i.e., abandoning the monastic order, breaking the vows]: oh, in vain this abominable fear of danger, plaintive wails or some pretend horror [daunts] our hearts, I won't be daunted, standing with this flag, by Styx's troops [i.e., fear of death], by greedy light [i.e., greed for fame], by ill-fated Thago [i.e., gold], or gifts of treacherous Dione [i.e., carnal desires]. / The shimmer of this flag coming from afar will instil fear to the enemy's flying flags no matter what their number: this [i.e., Christ's] flag is always accompanied / by victory that decorates its sacred tip with green laurel. / Oh, the flag that never suffers a defeat, it is worthy to be at the royal throne! Never will I be torn away from it [i.e., I will not break the vows]!)

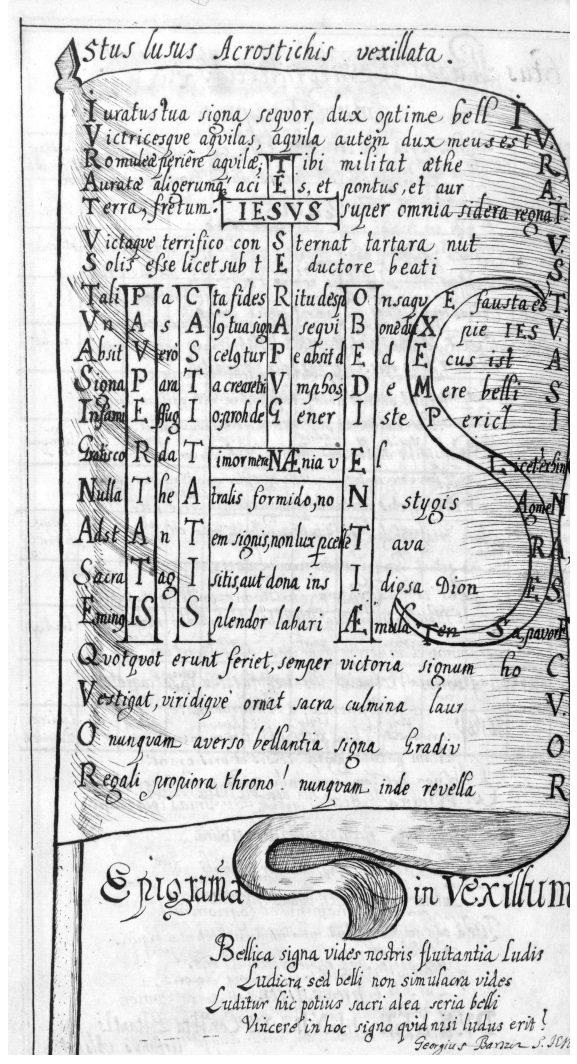

Fig. 2. 
This work is dedicated to Jesuits' three main vows: poverty (paupertas), chastity (castitas), and obedience (obedientia). In this text, which is saturated with complex and ingenious Christian and Classical allegories and allusions, the poet glorifies the Christian faith. On the day of tiaking monastic vows, the subject of the work joined Christ's immense and invincible troops, and there do not exist earthly riches or other temptations that could keep them away from the true purpose, faith and labouring for its good (ad maiorem Dei gloriam). This shaped text, which made great demands in terms of time and ingenuity on the writer, is like the young Jesuit's meditation on the theme of faith, a confirmation of monastic vows.

The work of the Piarist monk Krzyżkiewicz turns into a source of inspiration to the Jesuit to use the same form for a reflection on his main aspiration service to God. The subject of Krzyżkiewicz's work is a courageous and pious king defending Catholicism on a battlefield. In Barszcz's poem, the subject is a monk who rejects the earthly goods and temptations, abandons himself to Christ, and dedicates all his efforts to the consolidation and spread of faith.

\section{Conclusions}

In the seventeenth and eighteenth centuries, teaching of poetics and rhetoric in the Jesuit colleges of the Grand Duchy of Lithuania followed one common model, which shaped the students' attitude to literature. Considerable attention was paid on the reading and analysis of works by Classical authors and those of the period discussed. The regulations of Jesuit teaching demanded that a student should not only read and understand a work, but also compose something similar himself. Therefore, after sufficient theory had been internalised, students' independent creative work was strongly encouraged. Sometimes it remained within the boundaries of rules and examples, while at other times students' practice developed into genuinely new and original works.

The theory of imitation took an important place in the classes of poetics and rhetoric. Imitation was divided into literal (imitatio verborum) and imitation of feelings or content (imitatio sensuum seu rerum). In the former case, students imitated the eloquence and lexicon of a chosen author, and in the latter, it was the feelings experienced while reading a particular work. The latter imitation was considered much more complex as it placed great demands on the writer's innate talent, mastery of the rules, and personal ingenuity. It was mostly this type of imitation that turned into an inspiration for a completely new and original work. 
A Quest for Originality in Latin Poetry of the Grand Duchy of Lithuania

The attempts at individual creative work of the students of Jesuit colleges of the Grand Duchy of Lithuania that survive in manuscripts show that in their works they not only blindly followed texts by chosen authors, but searched for new ways and means of expression. Quite often a work by a chosen author would become just a starting point or a mental aspiration in composing an entirely new work in one genre or another. Jesuit students in the Grand Duchy of Lithuania left quite a number of texts that we could refer to as original and on a par with creative work of the best poets of that time. These texts demonstrate the desire of young poets to apply theoretical rules, the accumulated knowledge and erudition, and at the same time we observe the desire to look for their own creative path and new means of expression.

\author{
Živilè Nedzinskaitè \\ zivile.nedzinskaite@gmail.com \\ Lietuvių literatūros ir tautosakos institutas \\ Antakalnio g. 6 \\ LT-10308 Vilnius \\ LIETUVA / LITHUANIA
}

\title{
Sources and bibliography
}

BCz 1866 IV. 1695. Fructus horni meditationis rhetoricae Crosis ab academicis Societatis Iesu fusi [---].

Becker, U. 1996. Simbolių žodynas. Vilnius: Vaga.

Böhmer, H. 1904. Die Jesuiten. Eine historische Skizze. Leipzig und Berlin: Verlag von B. G. Teubner.

Elenchus librorum veteris collegii Crosensis anno 1803 compilatus // Buvusios Kražių kolegijos 1803 metų knygų sąrašas, parengè Darius Antanavičius. 2017. Vilnius: Lietuvių literatūros ir tautosakos institutas.

Encyklopedia wiedzy o jezuitach na ziemiach Polski i Litwy 1564-1995, opr. Ludwig Grzebień SJ. 1996. Kraków: Wydawnictwo WAM.

[Krzyżkiewicz, A.]. 1674. Attica Musa Thitoream et Hyampeum, Parnassi colles, ultro et citro pervolans, seu epitome artis poeticae authore $p$ [atre] Ignatio a S[ancto] Francisco religionis P. M. D. Scholarum Piarum. Cracoviae: Apud Albertum Gorecki, S. R. M. Typ.

Natoński, B. 1970. Szkolnictwo jezuickie w Polsce w dobie kontrreformacji. - Wiek XVII. Kontrreformacja. Barok. Prace $z$ historii kultury, pod red. Janusza Pelca. Wrocław [i inn.]: Zakład Narodowy im. Ossolińskich, 309-337.

Nedzinskaitè, Ž. 2011. „Tepaliks kiekvienas šlovę po savęs ...": Motiejaus Kazimiero Sarbievijaus poetikos ir poezijos recepcija XVII-XVIII amžiaus LDK jėzuitu edukacijos sistemoje (Senosios literatūros studijos). Vilnius: Lietuvių literatūros ir tautosakos institutas. 
NEDZINSKAITE்

Orłowski, D. 2007. Chocim 1673. Warszawa: Belona.

Piechnik, L. 1984. Początki Akademii Wileńskiej (1569-1600). Rzym: Institutum Historicum Societatis Jesu.

Pontanus, J. 1609. Institutio poetica. Coloniae: Sumptibus Bernardi Gualtheri.

Rabikauskas, P. 2002. Vilniaus akademija ir Lietuvos jėzuitai, sudarè Liudas Jovaiša. Vilnius: Aidai.

Ratio atque institutio studiorum Societatis Iesu. 1603. Turnoni: Apud Claudium Michaelem typographum universitatis.

Sarbievius, M. C. 1632. Lyricorum libri IV, epodon liber unus alterque epigrammatum. Antverpiae: Ex officina Plantiniana Balthasaris Moreti.

Scaliger, J. C. 1586. Poetices. Libri septem. Lyons: Apud Petrum Santandreanum.

Šidlauskas, A. 1989. Istorija Vilniaus universitete XVI a. pabaigoje - XIX a. pradžioje. Vilnius: Mokslas.

Ulčinaitè, E. 1979. Retorika Vilniaus universitete XVI-XVII a. - Literatūra, 25(3), 8-10.

Ulčinaitè, E. 1995. Tradycja i nowatorstwo w wykładach retoryki w kolegiach jezuickich w XVII-XVIII wieku. - Jezuicka ars educandi. Prace ofiarowane księdzu profesorowi Ludwikowi Piechnikowi SJ. Kraków: Wydawnictwo WAM, 241-252.

VUB RS F 3-1364. 1703. Domus Ciceronis Polonae eloquentiae [...] ad literalia studia redeuntibus rhetoribus collegii Grodnensis [...].

VUB RS F 3-1392. [Rhetorica, 17-18 century].

VUB RS F 3-1395. [Poetica, 17-18 century].

VUB RS F 3-2188. 1694. Tyrocinium eloquentiae Matthiae Troyniewicz sub Michaele Suffczynski.

VUB RS F 3-68. 1651. Quatuor beatitudines a divo Luca descriptae et pro festo sanctorum Cosmae et Damiani martyrum in ecclesia recitatae ab academicis eloquentiae auditoribus Societatis Iesu religiosa vota nuncupantibus exaggerantur.

VUB RS F 3-938. 1734. Poeta proprio decorus nomine [... in Crosensi Chodkieviciano ligatae eloquentiae palaestra SI ligatus. 